\title{
Phytosociology of Two Caatinga Phytophysiognomies with Different Histories of Anthropic Disturbance
}

\author{
Diego Meireles Monteiro ${ }^{1}$ (D) 0000-0001-7767-8993 \\ Bruno Coutinho Kurtz ${ }^{2}$ (D) 0000-0003-0306-4969
}

\begin{abstract}
The Caatinga (dryland) vegetation of northeastern Brazil has become highly anthropized while still poorly studied, with little research evaluating its potential for natural regeneration. This study sought to compare the compositions and structures of the shrub-arboreal components of two Caatinga areas with different histories of anthropic disturbance in the Negreiros National Forest, Pernambuco State, Brazil. Twelve $4 \times 50 \mathrm{~m}$ plots were established in each area, sampling all individuals $\geq 1 \mathrm{~m}$ tall with stem diameters at ground level $\geq 3 \mathrm{~cm}$. A total of 34 species were sampled. The two areas had very distinct structures, with different dominant species: Croton blanchetianus, Poincianella pyramidalis, and Croton sp. in the conserved area; and Cnidoscolus quercifolius and Aspidosperma pyrifolium in the anthropogenically impacted area. The presence of cattle grazing appears to be negatively interfering with the recuperation of the anthropized area, which continues as a phytophysiognomically open site more than 30 years after discontinuing agricultural activities.
\end{abstract}

Keywords: Negreiros National Forest, tropical dry forest, cattle, natural regeneration.

\section{INTRODUCTION AND OBJECTIVES}

Tropical dry forests (TDFs) are among the most threatened but least-studied forest ecosystems in the world (e.g., Miles et al., 2006; Sunderland et al., 2015). They can be characterized as forest formations in tropical regions experiencing summer rains, low annual precipitation levels (500-1,500 $\mathrm{mm}$ ), and strong seasonality in terms of rainfall distribution (5-8 dry months) (Sunderland et al., 2015). In response to those climatic conditions, TDFs have similar structures and physiognomies (Miles et al., 2006), including high percentages of deciduous species in their shrub-arboreal components (Apgaua et al., 2014; DryFlor, 2016).

In the first decade of the present century, TDF remnants were estimated to cover $1,048,700 \mathrm{~km}^{2}$ globally, with slightly more than half of that area in South America. In general, those remnant areas are threatened by climate change, fragmentation, fire, conversion to agricultural lands, and/or human demographic pressures (Miles et al., 2006). Research priorities designed to subsidize global, regional, and national policies related to TDFs include inventories to evaluate their floristics and biogeographies (Sunderland et al., 2015).
The largest continuous areas of TDFs in Brazil are found in the Brazilian Caatinga biome (DryFlor, 2016) that covers all of the northeastern states of that country, as well as the northern portion of Minas Gerais State. The biome covers approximately $844,000 \mathrm{~km}^{2}$ under the influence of a generally semiarid climate (IBGE, 2004), within a predominantly woody and xerophilic vegetation of deciduous shrubs and small trees that are generally spiny, together with the presence of succulent cacti and a seasonal herbaceous stratum (Apgaua et al., 2014; Pereira Filho et al., 2010). On local scales, the shrub-arboreal components generally show low richness, with very few numerically and/or structurally preponderant species (see Moro et al., 2015 and references).

Contrary to the common view of Caatinga biome, it demonstrates great heterogeneity of biotic and abiotic factors throughout its distribution (Velloso et al., 2002); its biota is rich in species and endemism, although it is one of the most degraded Brazilian biomes due to anthropic impacts (Silva et al., 2003). Its flora, for example, includes 4,659 species of seed plants, with 913 (19.6\%) endemic taxa (Zappi et al., 2015).

According to Leal et al. (2005), the main threats to the conservation of the Caatinga region are related to its dense

\footnotetext{
${ }^{1}$ Instituto Chico Mendes de Conservação da Biodiversidade (ICMBio), Recife, PE, Brasil

${ }^{2}$ Instituto de Pesquisas Jardim Botânico do Rio de Janeiro (JBRJ), Rio de Janeiro, RJ, Brasil
} 
human occupation (more than 25 million people; 15\% of Brazil's population at the beginning of the 21 st century). Its rural populations are extremely poor and many common activities are unsustainable, such as wood harvesting, hunting, slash and burn agriculture, and deforestation to create pasture for cattle and goats - all of which intensify desertification processes and threaten regional biodiversity. According to the Brazilian Forest Service (Ibama, [2018?]), fully $46 \%$ of the Caatinga vegetation had been impacted by 2009. Additionally, Guedes et al. (2012) pointed out that even areas considered well-conserved show signs of past use; only $1.3 \%$ of the biome is currently included in full-protection legal conservation areas (MMA, [2018?]).

Although the Caatinga vegetation is still poorly studied, the numbers of floristic - phytosociological inventories have greatly increased in recent decades (see Moro et al., 2015). Few studies, however, have compared (at local scales) conserved areas with regenerating sites impacted by different anthropic disturbances (e.g., Andrade et al., 2005; Madeira et al., 2009; Pereira et al., 2003; Silva et al., 2012) studies that would allow the quantification of the observed differences in their vegetation compositions and structures and evaluations of their natural regeneration capacities. That type of information would be of strategic importance to the highly threatened and disturbed Caatinga biome. At a global scale, for example, different properties related to structure and diversity of TDFs show potential for recuperation after severe anthropic disturbances on timescales stretching to decades (Pulla et al., 2015).

As such, the present study sought to compare the floristic composition and structure of the shrub-arboreal component of a well-conserved Caatinga site to another area that has been recuperating from previous farming, both within the Negreiros National Forest, Pernambuco State, Brazil.

\section{MATERIALS AND METHODS}

\subsection{Study area}

The present study was conducted in the Negreiros National Forest - NNF (Figure 1) administrated by the Brazilian National Park Service - ICMBio. The NNF is located within the semiarid region of Pernambuco State, Brazil, in the municipalities of Serrita and Parnamirim $\left(7^{\circ} 57^{\prime}-8^{\circ} 0^{\prime} \mathrm{S}\right.$; $39^{\circ} 22^{\prime}-39^{\circ} 29^{\prime} \mathrm{W}$ ); it was created by Federal Decree on October 11, 2007. The NNF occupies approximately 3,000 hectares within the Caatinga biome (ICMBio, [2017?]) between the Northern and Meridian Sertaneja Depressions
(Velloso et al., 2002). The local climate is hot, with rainfall concentrated between December and April (annual mean of $622 \mathrm{~mm}$ ) and an annual mean temperature of $24.3^{\circ} \mathrm{C}$ (type BSh by the Köppen classification) (Climate-Data, [2017?]).

The NNF comprises two very distinct phytophysiognomies: a conserved, closed shrub-arboreal Caatinga with no apparent intense use of its forest resources in the last 30 years; and a more open and anthropogenically impacted shrub-arboreal Caatinga formation. Approximately 40 years ago (according to local residents), the latter area was cut and burned extensively to form small agricultural plots (e.g., cultivating tomatoes). Historic Google Earth images suggest that those activities had already been abandoned in the mid-1980s, although the area was then used as otherwise unimproved (natural) pasture for cattle (up to 4,000 heads). The conserved site was rarely used for grazing purposes. The original regional vegetation is classified as Forested Savanna-Steppe (IBGE, 2012), with highly branched, low trees and shrubs, generally with thorns or spines, that are completely deciduous in the dry season.

\subsection{Vegetation surveys}

The vegetation survey employed a plot methodology (Mueller-Dombois \& Ellenberg, 1974), with a total of twentyfour $4 \times 50 \mathrm{~m}$ plots: 12 plots in the closed shrub-arboreal phytophysiognomy (area 1: considered here as "conserved"), and 12 plots in the open shrub-arboreal phytophysiognomy (area 2: "anthropized"). Those phytophysiognomies were identified during field excursions and analyses of Google Earth images. The distribution of the plots in area 1 used an intermittent watercourse as a reference axis, dividing it into $100 \mathrm{~m}$ sections and then randomly choosing plot areas on either bank (right or left). The plots were installed $30 \mathrm{~m}$ from the intermittent watercourse to avoid any direct influences from it. The plots were established with east-west orientations. Area 2 was established similarly, except that a dirt road was used as the reference axis (Figure 1). The plots were established at elevations between 420 and $460 \mathrm{~m}$ a.s.l. The surveys included all live woody plants (except lianas) with heights $\geq 1 \mathrm{~m}$ and stem diameters at ground level $\geq 3 \mathrm{~cm}$ (Rodal et al., 2013). The plants were pre-identified in the field and measured (heights and diameters). Fertile (or sterile) botanical material was collected to confirm plant identifications (by specialists). Testimony materials of the identified species were deposited in the HVASF herbarium at the Universidade Federal do Vale do São Francisco, and in the RB herbarium at the Instituto de Pesquisas Jardim Botânico do Rio de Janeiro (JBRJ). The species names are based on JBRJ ([2017?]). 


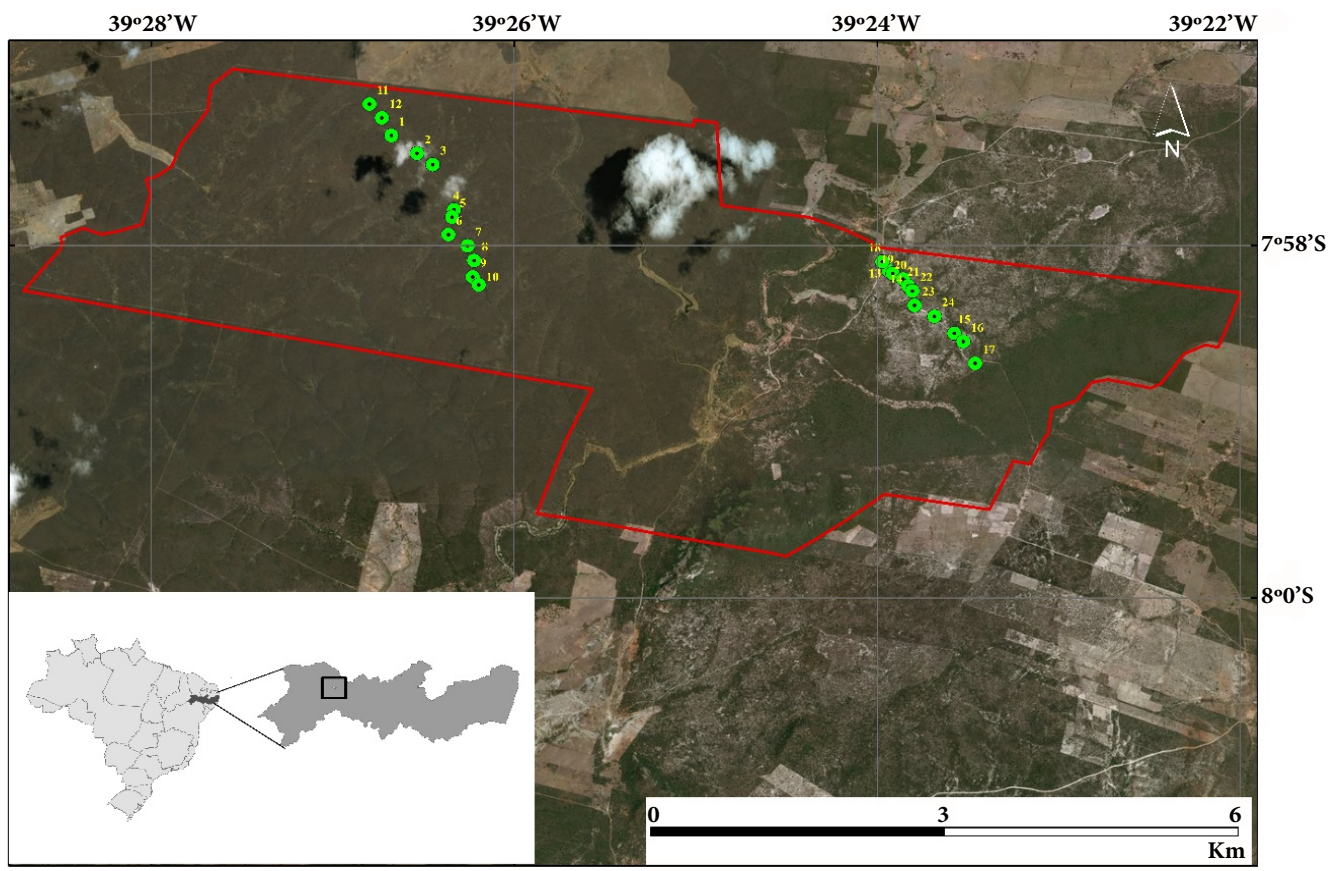

Figure 1. GeoEye image of the Negreiros National Forest, Pernambuco State, Brazil, showing the locations of the sampling plots established in the two Caatinga phytophysiognomies. Plots 1 to 12: conserved area; plots 13 to 24: anthropized area.

\subsection{Data treatment}

Evaluations of sampling sufficiency were performed based on randomized species accumulation curves (Colwell \& Coddington, 1994) constructed using Estimates 9.1 software (Colwell, [2017?]). Density, frequency, dominance and importance value parameters were calculated for each species (MuellerDombois \& Ellenberg, 1974), and the Shannon diversity (H') and equitability ( $\left({ }^{\prime}\right)$ indices were calculated for each area (natural $\log )(Z a r, 1996)$. Grouping analysis was also performed using the 24 plots, based on the numbers of individuals of each species, employing Bray-Curtis distances and the Ward method for dendrogram construction (Valentin, 2000). Those calculations were performed using Fitopac 1.6 software (Shepherd, 2006).

Comparisons were made between the densities, basal areas, and mean diameters of the shrub-arboreal components of the two study areas using the t-test; the mean height values did not conform to the assumption of homoscedasticity of the variances and were compared using the Mann-Whitney nonparametric test (Zar, 1996). Those calculations were performed using Statistica 8.0 software (StatSoft, [2017?]). The Shannon indices of the areas were also compared using the t-test proposed by Hutcheson, according to Zar (1996). Diameter class histograms were constructed to evaluate the behaviors of the most numerous populations (species comprising more than 50 individuals) in each area, according to the methodology proposed by Spiegel (1970).

\section{RESULTS}

The accumulation curves of the species in the two survey areas demonstrated the tendency to stabilize (Figure 2), indicating that our sampling efforts allowed a statistically satisfactory characterization of the principal populations in each area.

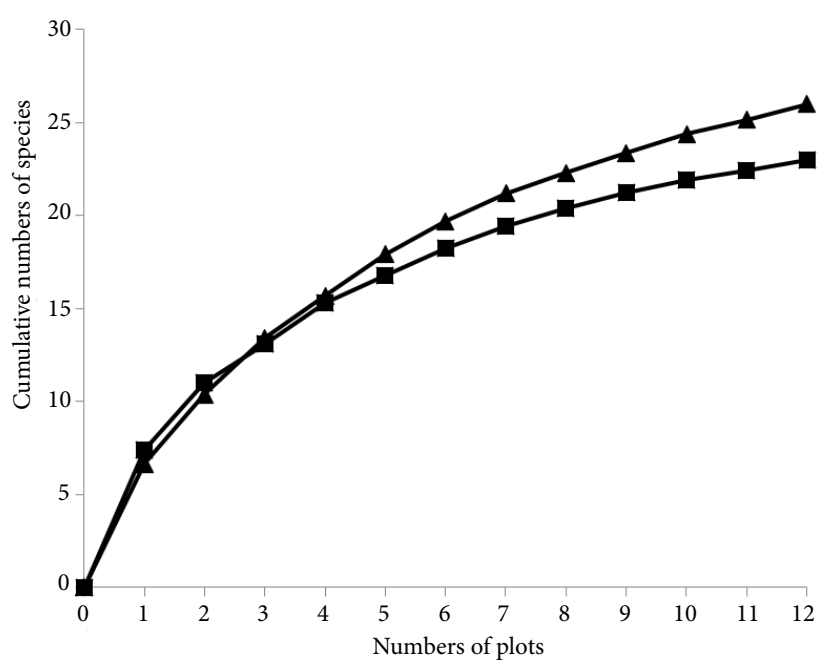

Figure 2. Randomized accumulation curves of the shrub-arboreal species (collection curves) in two Caatinga phytophysiognomies in the Negreiros National Forest, Pernambuco State, Brazil. Squares: area 1 (conserved); triangles: area 2 (anthropized). 
A total of 665 live individuals were sampled, representing 34 species, 30 genera, and 16 families (Table 1). A total of 413 individuals belonging to 23 species, 21 genera, and 11 families were found in area 1 ; while 252 individuals belonging to 26 species, 23 genera, and 13 families were found in area 2. Eight species were exclusive to area 1 and 11 species exclusive to area 2 , while 15 species were common to both areas. The most species-rich families in both areas were Fabaceae (10 species total) and Euphorbiaceae (7).

In area 1, the species Croton blanchetianus (IV $=65.52)$, Poincianella pyramidalis (59.92), and Croton sp. (37.95) stood out for their importance - totaling $~ 75 \%$ of all individuals sampled. In area 2 , the most important species were Cnidoscolus quercifolius (IV $=67.57)$ and Aspidosperma pyrifolium (54.94), totaling $~ 58 \%$ of all individuals sampled. Those data clearly demonstrate that the two areas have very distinct phytosociological structures, even $30+$ years after discontinuing agricultural activities in area 2. The dendrogram presented in Figure 3 demonstrates the formation of two groups of plots that correspond to the two study areas, reinforcing the differences between them.

Table 1. Phytosociological parameters of shrub-arboreal species in conserved (area 1) and anthropized (area 2) Caatinga sites in the Negreiros National Forest, Pernambuco State, Brazil.

\begin{tabular}{|c|c|c|c|c|c|c|c|c|c|c|}
\hline \multirow{2}{*}{ Family/species } & \multicolumn{5}{|c|}{ Area 1} & \multicolumn{5}{|c|}{ Area 2} \\
\hline & $\mathbf{N}$ & RD & RF & RDo & IV & $\mathbf{N}$ & RD & RF & RDo & IV \\
\hline \multicolumn{11}{|l|}{ Anacardiaceae } \\
\hline Myracrodruon urundeuva Allemão & 7 & 1.69 & 7.87 & 10.61 & 20.17 & 1 & 0.4 & 1.22 & 1.82 & 3.44 \\
\hline Spondias tuberosa Arruda & 1 & 0.24 & 1.12 & 3.71 & 5.08 & 1 & 0.4 & 1.22 & 17.75 & 19.37 \\
\hline \multicolumn{11}{|l|}{ Annonaceae } \\
\hline Annona leptopetala (R.E. Fr.) H. Rainer & & & & & & 1 & 0.4 & 1.22 & 0.21 & 1.83 \\
\hline \multicolumn{11}{|l|}{ Apocynaceae } \\
\hline Aspidosperma pyrifolium Mart. \& Zucc. & 2 & 0.48 & 1.12 & 0.12 & 1.73 & 61 & 24.21 & 12.2 & 18.54 & 54.94 \\
\hline Calotropis procera (Aiton) W.T. Aiton & & & & & & 1 & 0.4 & 1.22 & 0.07 & 1.68 \\
\hline \multicolumn{11}{|l|}{ Bignoniaceae } \\
\hline Handroanthus impetiginosus (Mart. ex DC.) Mattos & & & & & & 2 & 0.79 & 1.22 & 1.78 & 3.79 \\
\hline \multicolumn{11}{|l|}{ Bixaceae } \\
\hline Cochlospermum vitifolium (Willd.) Spreng. & & & & & & 2 & 0.79 & 2.44 & 0.34 & 3.57 \\
\hline \multicolumn{11}{|l|}{ Boraginaceae } \\
\hline Varronia leucocephala (Moric.) J.S. Mill. & 1 & 0.24 & 1.12 & 0.14 & 1.51 & 1 & 0.4 & 1.22 & 0.08 & 1.69 \\
\hline \multicolumn{11}{|l|}{ Burseraceae } \\
\hline Commiphora leptophloeos (Mart.) J.B. Gillett & 2 & 0.48 & 2.25 & 1.81 & 4.54 & 5 & 1.98 & 6.1 & 10.97 & 19.05 \\
\hline \multicolumn{11}{|l|}{ Cactaceae } \\
\hline Cereus jamacaru DC. & 3 & 0.73 & 2.25 & 0.54 & 3.51 & & & & & \\
\hline $\begin{array}{l}\text { Pilosocereus gounellei (F.A.C. Weber) Byles \& } \\
\text { Rowley }\end{array}$ & & & & & & 1 & 0.4 & 1.22 & 0.49 & 2.11 \\
\hline \multicolumn{11}{|l|}{ Capparaceae } \\
\hline Cynophalla hastata (Jacq.) J. Presl & 9 & 2.18 & 6.74 & 0.89 & 9.81 & & & & & \\
\hline \multicolumn{11}{|l|}{ Caricaceae } \\
\hline Jacaratia corumbensis Kuntze & 1 & 0.24 & 1.12 & 0.04 & 1.41 & & & & & \\
\hline \multicolumn{11}{|l|}{ Celastraceae } \\
\hline Fraunhofera multiflora Mart. & 6 & 1.45 & 4.49 & 2.4 & 8.34 & 5 & 1.98 & 3.66 & 0.89 & 6.53 \\
\hline \multicolumn{11}{|l|}{ Euphorbiaceae } \\
\hline Cnidoscolus bahianus (Ule) Pax \& K. Hoffm. & & & & & & 11 & 4.37 & 7.32 & 1.61 & 13.3 \\
\hline Cnidoscolus quercifolius Pohl & 4 & 0.97 & 3.37 & 0.6 & 4.94 & 85 & 33.73 & 14.63 & 19.21 & 67.57 \\
\hline Croton blanchetianus Baill. & 165 & 39.95 & 13.48 & 12.09 & 65.52 & 20 & 7.94 & 9.76 & 2.07 & 19.77 \\
\hline Croton sp. & 67 & 16.22 & 10.11 & 11.62 & 37.95 & & & & & \\
\hline Jatropha ribifolia (Pohl) Baill. & 1 & 0.24 & 1.12 & 0.04 & 1.4 & 3 & 1.19 & 3.66 & 0.12 & 4.97 \\
\hline Manihot carthagenensis (Jacq.) Müll. Arg. & 5 & 1.21 & 4.49 & 0.68 & 6.39 & & & & & \\
\hline Sapium glandulosum (L.) Morong & & & & & & 13 & 5.16 & 6.1 & 5.17 & 16.43 \\
\hline
\end{tabular}


Table 1. Continued...

\begin{tabular}{|c|c|c|c|c|c|c|c|c|c|c|}
\hline \multirow{2}{*}{ Family/species } & \multicolumn{5}{|c|}{ Area 1} & \multicolumn{5}{|c|}{ Area 2} \\
\hline & $\mathbf{N}$ & RD & RF & RDo & IV & $\mathbf{N}$ & RD & RF & RDo & IV \\
\hline \multicolumn{11}{|l|}{ Fabaceae } \\
\hline Amburana cearensis (Allemão) A.C. Sm. & 1 & 0.24 & 1.12 & 1.01 & 2.38 & 12 & 4.76 & 4.88 & 4.03 & 13.67 \\
\hline Anadenanthera colubrina (Vell.) Brenan & 5 & 1.21 & 3.37 & 7.52 & 12.1 & 2 & 0.79 & 1.22 & 5.09 & 7.1 \\
\hline Bauhinia cheilantha (Bong.) Steud. & 8 & 1.94 & 5.62 & 1.31 & 8.87 & & & & & \\
\hline Libidibia ferrea (Mart. ex Tul.) L.P. Queiroz & & & & & & 1 & 0.4 & 1.22 & 0.97 & 2.59 \\
\hline Mimosa tenuiflora (Willd.) Poir. & 4 & 0.97 & 2.25 & 6.48 & 9.7 & 5 & 1.98 & 3.66 & 5.18 & 10.82 \\
\hline Mimosa sp. & 25 & 6.05 & 8.99 & 3.61 & 18.65 & 4 & 1.59 & 3.66 & 0.49 & 5.73 \\
\hline $\begin{array}{l}\text { Parapiptadenia zehntneri (Harms) M.P. Lima \& } \\
\text { H.C. Lima }\end{array}$ & 2 & 0.48 & 2.25 & 0.08 & 2.81 & & & & & \\
\hline Piptadenia stipulacea (Benth.) Ducke & 17 & 4.12 & 2.25 & 4.24 & 10.61 & 3 & 1.19 & 1.22 & 0.36 & 2.77 \\
\hline Poincianella pyramidalis (Tul.) L.P. Queiroz & 76 & 18.4 & 12.36 & 29.16 & 59.92 & 8 & 3.17 & 4.88 & 1.42 & 9.47 \\
\hline Fabaceae sp. & & & & & & 2 & 0.79 & 2.44 & 0.26 & 3.49 \\
\hline \multicolumn{11}{|l|}{ Malvaceae } \\
\hline $\begin{array}{l}\text { Pseudobombax marginatum (A. St.-Hil., Juss. \& } \\
\text { Cambess.) A. Robyns }\end{array}$ & & & & & & 1 & 0.4 & 1.22 & 1.03 & 2.65 \\
\hline \multicolumn{11}{|l|}{ Rhamnaceae } \\
\hline Ziziphus joazeiro Mart. & 1 & 0.24 & 1.12 & 1.3 & 2.67 & & & & & \\
\hline \multicolumn{11}{|l|}{ Verbenaceae } \\
\hline Lippia origanoides Kunth & & & & & & 1 & 0.4 & 1.22 & 0.05 & 1.67 \\
\hline
\end{tabular}

$\mathrm{N}$ : number of individuals surveyed; RD: relative density (\%); RF: relative frequency (\%); RDo: relative dominance (\%); IV: importance value

The $\mathrm{H}^{\prime}$ values for areas 1 and 2 were 1.96 and 2.21, and the J' values 0.63 and 0.68 , respectively. The diversities of the two areas were quite distinct, with the $H^{\prime}$ value of area 2 being significantly greater than that of area 1 $(t=-2.412 ; p<0.01)$. There were also significant differences between the two areas in terms of plant densities and mean plant diameters, with greater density in area 1 $(\mathrm{t}=3.879 ; p<0.001)$ and greater mean stem diameters in area $2(\mathrm{t}=-2.416 ; p=0.024)$. There were no significant differences between the basal areas $(\mathrm{t}=0.562 ; p=0.579)$ or mean heights $(\mathrm{Z}=1.472 ; p=0.141)$ of the plants in the two areas (Table 2).

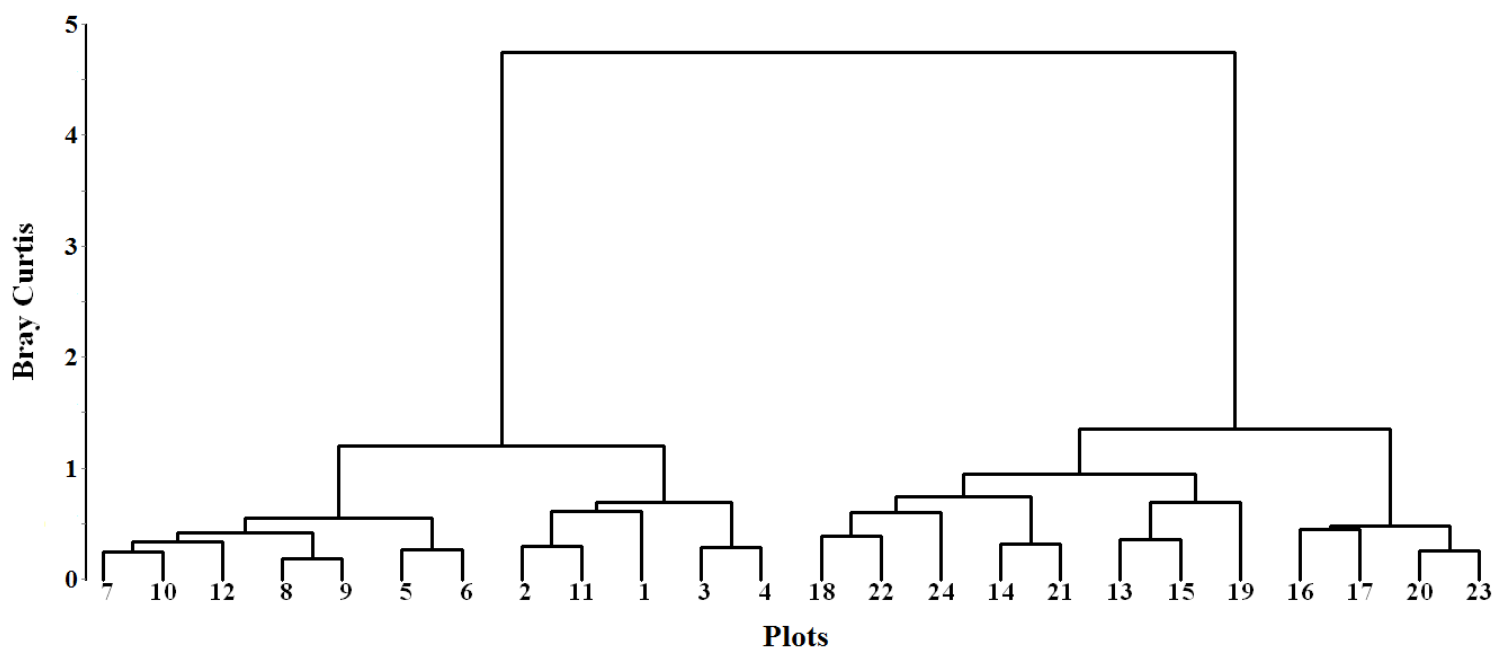

Figure 3. Dendrogram of the cluster analysis of the shrub-arboreal components in 24 plots implanted in two Caatinga phytophysiognomies in the Negreiros National Forest, Pernambuco State, Brazil. Ward's method. Plots 1 to 12: conserved area; plots 13 to 24: anthropized area. Cophenetic correlation coefficient $=0.83$. 
Table 2. Comparisons between the quantitative parameters of the two Caatinga phytophysiognomies in the Negreiros National Forest, Pernambuco State, Brazil. Area 1 (conserved); area 2 (anthropized). Density, basal area, and mean diameter: t-test; diversity: Hutcheson t-test; mean height: Mann-Whitney test; $\alpha=0.05$.

\begin{tabular}{|c|c|c|c|c|c|}
\hline Area & Parameter & $\begin{array}{c}\text { Mean } \pm \\
\text { Standard } \\
\text { deviation }\end{array}$ & Value & $p$ & Result \\
\hline $\begin{array}{l}1 \\
2\end{array}$ & $\begin{array}{l}\text { Density } \\
\left(\text { ind.ha }^{-1}\right)\end{array}$ & $\begin{array}{c}1,720.8 \pm 397.4 \\
1,050 \pm 448.2\end{array}$ & $\mathrm{t}=3.879$ & $<0.001$ & $1>2$ \\
\hline $\begin{array}{l}1 \\
2\end{array}$ & $\begin{array}{c}\text { Basal area } \\
\left(\mathrm{m}^{2} \cdot \mathrm{ha}^{-1}\right)\end{array}$ & $\begin{array}{c}11.4 \pm 5.2 \\
9.7 \pm 9.1\end{array}$ & $t=0.562$ & 0.579 & $1=2$ \\
\hline $\begin{array}{l}1 \\
2\end{array}$ & $\begin{array}{c}\text { Mean } \\
\text { height }(\mathrm{m})\end{array}$ & $\begin{array}{l}4.2 \pm 0.3 \\
3.9 \pm 0.5\end{array}$ & $Z=1.472$ & 0.141 & $1=2$ \\
\hline $\begin{array}{l}1 \\
2\end{array}$ & $\begin{array}{c}\text { Mean } \\
\text { diameter } \\
(\mathrm{cm})\end{array}$ & $\begin{array}{l}7.3 \pm 0.8 \\
8.6 \pm 1.7\end{array}$ & $\mathrm{t}=-2.416^{*}$ & $0.024^{*}$ & $1<2$ \\
\hline $\begin{array}{l}1 \\
2\end{array}$ & $\begin{array}{l}\text { Diversity } \\
\left(\mathrm{H}^{\prime}\right)\end{array}$ & $\begin{array}{l}1.96 \pm 0.01 \\
2.21 \pm 0.02\end{array}$ & $\mathrm{t}=-2.412$ & $<0.01$ & $1<2$ \\
\hline
\end{tabular}

${ }^{\star}$ Data square root transformed to conform to the assumption of homoscedasticity of the variances.

The diameter distributions of the most abundant species in area 1 (Croton blanchetianus, Poincianella pyramidalis, and Croton sp.) and in area 2 (Cnidoscolus quercifolius and Aspidosperma pyrifolium) had the same approximate inverted ' $J$ ' shape, with the largest numbers of individuals in the smaller diameter classes and a general tendency of decreasing numbers in larger diameter classes (Figure 4). That distribution indicates the populations are stabilized, at least in terms of the minimum inclusion criteria adopted, suggesting their - at least mediumterm - persistence in their respective areas.

\section{DISCUSSION}

On a global scale, TDFs demonstrate the capacity to recuperate from severe disturbances such as cutting and burning for agriculture, wood extraction, conversion to pasture, or even storm damage or landslides, over time periods up to various decades - depending on the nature of the disturbance and the biological variable considered (Pulla et al., 2015). According to Vieira \& Scariot (2006), those forests are composed of high proportions of species with small, wind-dispersed seeds, well-developed abilities to root-sprout after severe disturbances, relatively simple structures, and low diversity - all of which provide them with high potential for recuperation.

Research objectively comparing, on local scales, the shrubarboreal components of conserved Caatinga areas with those having different disturbance histories has been relatively rare. Pereira et al. (2003) compared four areas in the municipality of Areia, in Paraíba State: one well-conserved site (little anthropic intervention in the past 50 years); and three sites subjected to different types and durations of use and recuperation: 1) selective cutting of some trees 16 years before; 2) natural regeneration for 30 years after 39 years of agricultural use; and 3) natural regeneration for 20 years after 35 years of agricultural use, followed by use as planted pasture for 15 years. Cattle had been allowed to freely graze for most of the year in all three anthropogenically impacted areas, but only very rarely in the conserved area. Those authors reported differences in the numbers of species, their densities, basal areas, mean diameters, and heights between the well-conserved site and the three anthropized sites, as well as differences between the three impacted areas themselves. There was a general pattern of reductions of the measured biological variables with increasing intensity of anthropic interference and reductions of natural regeneration times. They also encountered differences in floristic composition and phytosociological structures, mainly in the area used for a longer period of time (agriculture/planted pasture) and left to recuperate for a shorter period of time (20 years) - with strong domination by Mimosa tenuiflora (Willd.) Poir. The authors stressed that areas used for agriculture and then abandoned could require decades to reestablish their original states.

Madeira et al. (2009) compared the trees (DBH $\geq 5 \mathrm{~cm}$ ) encountered in three different successional areas of Caatinga in the municipality of Manga, in northern Minas Gerais State: 1) an area of late recuperation, without any record of clearing in the last 50 years; 2 ) an area in a medium state of recuperation, which had been used for grazing for an undetermined amount of time, but abandoned approximately 18 years earlier; and 3) an area in an initial state of recuperation, which had been used as pasture for at least 20 years but had been abandoned six years before initiating the study (although it was still used occasionally during that time for grazing). The pastures were established by clear-cutting the original vegetation, and then plowing and planting with exotic grasses; they were burned every two years immediately before the rainy season. Those authors noted increases in the heights, basal areas, densities, and numbers of species as well as the complexity of the arboreal component from the initial to the latest state of recuperation, with changes in species dominance along the successional gradient; the largest structural alterations occurred between the initial and intermediate stages (Madeira et al., 2009).

The results reported here for the NNF, however, indicated that (in terms of the variables examined) only the density of the shrub-arboreal component in the anthropogenically impacted area was smaller than in the conserved area, even $30+$ years after abandoning agricultural activities in the former site; the mean plant diameters and species diversity in the anthropogenically impacted area were actually larger than those observed in the conserved area, as occasionally seen in TDFs (Pulla et al., 2015). Those areas, however, demonstrated 
significant differences in terms of their floristic compositions and, mainly, their phytophysiognomies (open shrub-arboreal vs. closed shrub-arboreal) and phytosociological structures with different dominant species in each.

Although all the studies together indicate that Caatinga areas can naturally regenerate, many differences will persist in terms of the compositions and/or structures of their shrub-arboreal components in relation to more conserved reference sites. While they experienced different types and intensities of use

and were left to regenerate for different periods of time (which, of course, influenced their different successional trajectories), a recurrent factor for all of them (with the exception of the intermediate stage reported by Madeira et al. 2009) was the presence of cattle after the cessation of the main degrading factor. As such, even after "abandonment" those areas continued to be submitted to anthropic pressure (grazing), which negatively impacted their processes of natural regeneration (Andrade et al., 2005) and stunted their recuperation.
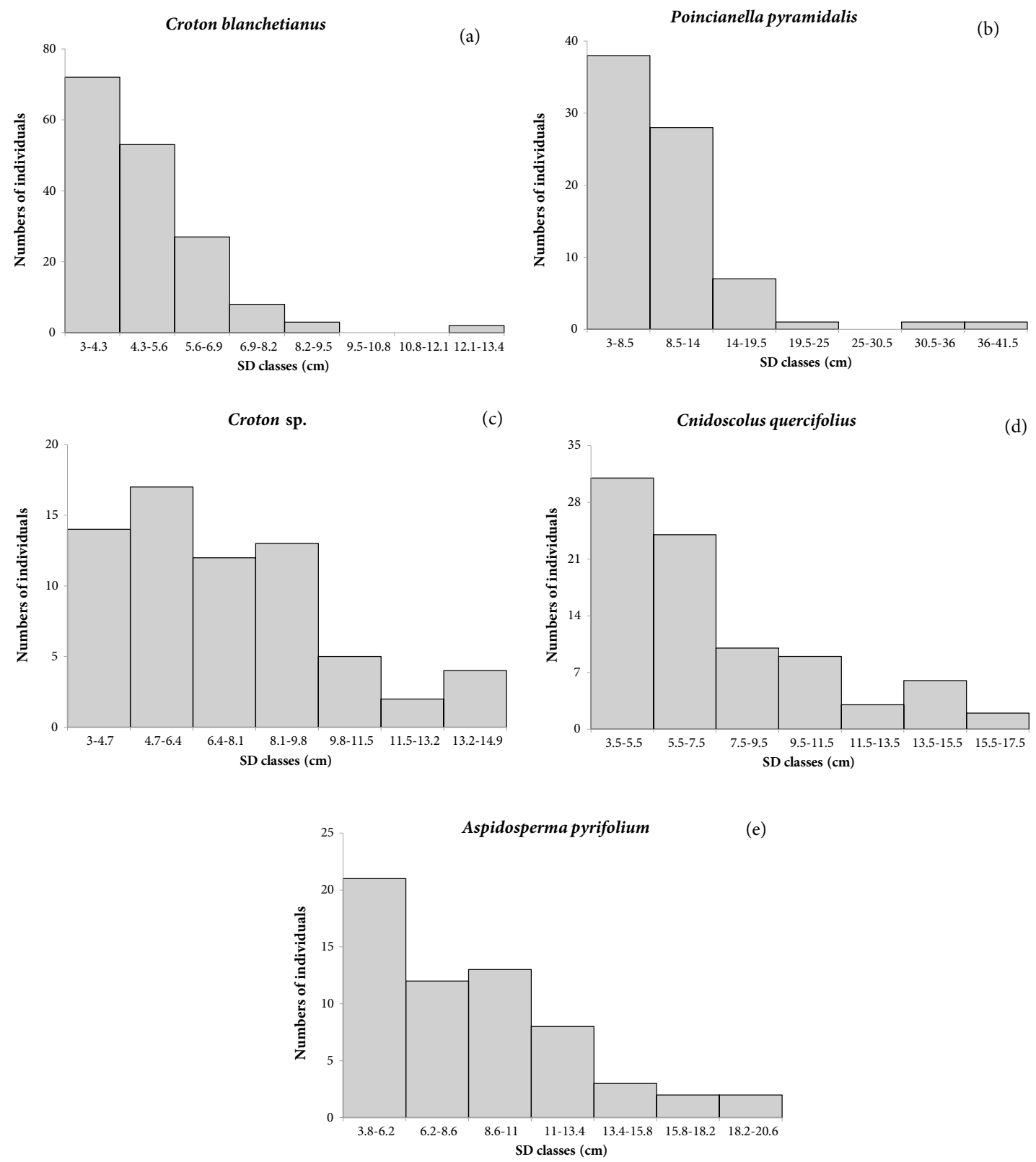

Figure 4. Stem diameter class distributions of shrub-arboreal species in two Caatinga phytophysiognomies in the Negreiros National Forest, Pernambuco State, Brazil. Conserved area: Croton blanchetianus (a), Poincianella pyramidalis (b), and Croton sp. (c). Anthropized area: Cnidoscolus quercifolius (d) and Aspidosperma pyrifolium (e). 
From a biodiversity conservation standpoint, grazing pressure represents one of the main problems in the Caatinga domain. Introduced at the beginning of the 16th century, cattle and goats continue to devastate a natural vegetation that was not evolutionarily adapted to intensive grazing pressure, and numerous desertification nuclei are now associated with overgrazing and trampling (see Leal et al., 2005). Many areas are used by large numbers of animals that selectively feed on young plants - which can lead to local extinctions of certain species (Pereira et al., 2003). Therefore, the common practice of freerange grazing in Caatinga vegetation must be impeded in sites designated for regeneration, as is the case of conservation areas.

The NNF is a good example of that problem: its anthropogenically impacted site is co-dominated by pioneer species (Cnidoscolus quercifolius and Aspidosperma pyrifolium) having physiological mechanisms to avoid/reduce grazing pressure. The former species produces unpalatable fresh leaves with urticant hairs (Coelho et al., 2012; Figueiredo et al., 2012), while the second is considered one of the most toxic plants in the Caatinga (Aquino et al., 2017; Silva et al., 2006). As those species are represented by only a few individuals with reduced phytosociological importance in the conserved area (which is rarely grazed), it appears that the introduction of grazing animals after abandoning agricultural activities selects for those pioneer species. The cleared area has maintained the same open phytophysiognomy since 1984 (in contrast to the conserved area), without any perceptible changes in the historic images available on Google Earth - apparently due to the prolonged presence of cattle (see Pulla et al., 2015). The strong dominance of Mimosa tenuiflora in the area experiencing the greatest grazing pressure in Areia (Pereira et al., 2003) is probably likewise related to the fact that it is toxic to ruminant animals (Silva et al., 2006).

The anthropogenically impacted area in the NNF is adjacent to well-conserved Caatinga areas, without any barriers to hinder the arrival of propagules from the latter that could contribute to natural regeneration. As many TDFs trees can re-sprout even after decades of grazing disturbance (Sampaio et al., 2007; Vieira et al., 2006), that capacity represents another route of potential regeneration. Our results, however, strongly suggest that the two areas remain different in terms of their phytophysiognomies and phytosociological structures due (at least in part) to constant grazing pressure. As such, and considering that the NNF is now completely fenced, the reserve administrators should remove all cattle and begin monitoring the natural regeneration of the anthropogenically impacted area. The removal of that stress factor and the evaluation of recovery would contribute to our understanding of the dynamics of the highly threatened but still little-known Caatinga biome.

\section{CONCLUSIONS}

The conserved and anthropized Caatinga phytophysiognomies in the Negreiros National Forest demonstrate significant differences in terms of their shrub-arboreal components even $30+$ years after the end of agricultural activities in the latter site. Although only the vegetation density is lower in the anthropized area than in the conserved area (among the biological variables examined), there are great differences in their floristic compositions and, mainly, in their phytophysiognomies and phytosociological structures. The anthropized area has been continually used for grazing, which apparently impacts its natural regeneration. Monitoring the vegetation in that area after removing all cattle from the interior of the NNF would confirm that supposition.

\section{ACKNOWLEDGEMENTS}

The authors would like to thank Anderson Lima and Carlos Leite, for their help during field activities, and Vinicius Messas Cotarelli, from the Universidade Federal do Vale do São Francisco (Univasf), for their collaboration in the identification of botanical material.

\section{SUBMISSION STATUS}

Received: 2 Feb. 2018

Accepted: 13 Sept. 2018

Associate editor: Rodrigo Studart Corrêa

(D) 0000-0002-9422-2629

\section{CORRESPONDENCE TO}

\section{Bruno Coutinho Kurtz}

Instituto de Pesquisas Jardim Botânico do Rio de Janeiro (JBRJ), Diretoria de Pesquisa Científica, Rua Pacheco Leão, 915, Jardim Botânico, CEP 22460-030, Rio de Janeiro, RJ, Brasil

e-mail: brunockurtz@gmail.com

\section{REFERENCES}

Andrade LA, Pereira IM, Leite UT, Barbosa MRV. Análise da cobertura de duas fitofisionomias de Caatinga, com diferentes históricos de uso, no município de São João do Cariri, estado da Paraíba. Cerne 2005; 11(3): 253-262.

Apgaua DMG, Santos RM, Pereira DGS, Menino GCO, Pires GG, Fontes MAL et al. Beta-diversity in seasonally dry tropical forests (SDTF) in the Caatinga Biogeographic Domain, Brazil, and its implications for conservation. Biodiversity and Conservation 2014; 23(1): 217-232. 10.1007/s10531-013-0599-9

Aquino RE, Falcão HM, Almeida-Cortez JS. Variação nas concentrações de compostos fenólicos e nas taxas de herbivoria em Aspidosperma pyrifolium Mart. em áreas antropizadas de Caatinga. Journal of Environmental Analysis and Progress 2017; 2(1): 61-71. 10.24221/jeap.2.1.2017.1075.61-71 
Climate-Data. Clima Serrita [Internet]. [2017?] [cited 2017 Dec. 15]. Available from: https://bit.ly/32iIzyM

Coelho MS, Belmiro MS, Santos JC, Fernandes GW. Herbivory among habitats on the Neotropical tree Cnidoscolus quercifolius Pohl in a seasonally deciduous forest. Brazilian Journal of Biology 2012; 72(3): 453-457. 10.1590/S1519-69842012000300006

Colwell RK. EstimateS: statistical estimation of species richness and shared species from samples, version 9 [Internet]. [2017?] [cited 2017 Oct. 15]. Available from: https://bit.ly/2r9Db46

Colwell RK, Coddington JA. Estimating terrestrial biodiversity through extrapolation. Philosophical Transactions of the Royal Society B 1994; 345(1311): 101-118. 10.1098/rstb.1994.0091

DryFlor. Plant diversity patterns in neotropical dry forests and their conservation implications. Science 2016; 353(6306): 1383-1387. $10.1126 /$ science.aaf5080

Figueiredo JM, Araújo JM, Pereira ON, Bakke IA, Bakke AO. Revegetation of degraded Caatinga sites. Journal of Tropical Forest Science 2012; 24(3): 332-343.

Guedes RS, Zanella FCV, Costa Júnior JEV, Santana GM, Silva JA. Caracterização florístico-fitossociológica do componente lenhoso de um trecho de Caatinga no semiárido paraibano. Revista Caatinga 2012; 25(2): 99-108.

Instituto Brasileiro de Geografia e Estatística - IBGE. Mapa de biomas do Brasil: primeira aproximação. Rio de Janeiro: IBGE; 2004.

Instituto Brasileiro de Geografia e Estatística - IBGE. Manual técnico da vegetação brasileira. 2nd ed. Rio de Janeiro: IBGE; 2012.

Instituto Brasileiro do Meio Ambiente e dos Recursos Naturais Renováveis - Ibama. Projeto de Monitoramento do Desmatamento dos Biomas Brasileiros por Satélite. Monitoramento da Caatinga: Caatinga [Internet]. [2018?] [cited 2018 June 1]. Available from: https://bit.ly/2JRnkxy

Instituto Chico Mendes de Conservação da Biodiversidade ICMBio. Flona de Negreiros [Internet]. [2017?] [cited 2017 Nov. 24]. Available from: https://bit.ly/2WNaG8f

Jardim Botânico do Rio de Janeiro - JBRJ. Flora do Brasil $2020 \mathrm{em}$ construção [Internet]. [2017?] [cited 2017 June 27]. Available from: https://bit.ly/33lexMg

Leal IR, Silva JMC, Tabarelli M, Lacher TE Jr. Mudando o curso da conservação da biodiversidade na Caatinga do Nordeste do Brasil. Megadiversidade 2005; 1(1): 139-146.

Madeira BG, Espírito-Santo MM, D’Ângelo Neto S, Nunes YRF, Azofeifa GAS, Fernandes GW, et al. Changes in tree and liana communities along a successional gradient in a tropical dry forest in south-eastern Brazil. Plant Ecology 2009; 201(1): 291-304. 10.1007/s11258-009-9580-9

Miles L, Newton AC, DeFries RS, Ravilious C, May I, Blyth S et al. A global overview of the conservation status of tropical dry forests. Journal of Biogeography 2006; 33(3): 491-505. 10.1111/j.13652699.2005.01424.x

Ministério do Meio Ambiente - MMA. Cadastro Nacional de Unidades de Conservação. Dados consolidados [Internet]. [2018?] [cited 2018 June 1]. Available from: https://bit.ly/3bFmcsb

Moro MF, Araújo FS, Rodal MJN, Martins FR. Síntese dos estudos florísticos e fitossociológicos realizados no semiárido brasileiro. In: Eisenlohr PV, Felfili JM, Melo MMRF, Andrade LA, Meira Neto JAA, editors. Fitossociologia no Brasil: métodos e estudos de caso. Vol. 2. Viçosa: Editora UFV; 2015. p. 412-451.

Mueller-Dombois D, Ellenberg H. Aims and methods of vegetation ecology. New York: John Wiley \& Sons; 1974.
Pereira IM, Andrade LA, Sampaio EVSB, Barbosa MRV. Use-history effects on structure and flora of Caatinga. Biotropica 2003; 35(2): 154-165. 10.1111/j.1744-7429.2003.tb00275.x

Pereira Filho JM, Vieira EL, Silva AMA, Cézar MF, Carvalho AM Jr. Efeito da altura de corte no controle da jurema-preta [Mimosa tenuiflora (Wild) Poir.]. Revista Caatinga 2010; 23(2): 51-58.

Pulla S, Ramaswami G, Mondal N, Chitra-Tarak R, Suresh HS, Dattaraja HS et al. Assessing the resilience of global seasonally dry tropical forests. International Forestry Review 2015; 17(S2): 91-113. $10.1505 / 146554815815834796$

Rodal MJN, Sampaio EVSB, Figueiredo MA, editors. Manual sobre métodos de estudo florístico e fitossociológico: ecossistema Caatinga. Brasília: Sociedade Botânica do Brasil; 2013.

Sampaio AB, Holl KD, Scariot A. Regeneration of seasonal deciduous forest tree species in long-used pastures in Central Brazil. Biotropica 2007; 39(5): 655-659. 10.1111/j.1744-7429.2007.00295.x

Shepherd GJ. Fitopac 1.6 (com FitopacShell): versão preliminar. Campinas: Unicamp; 2006.

Silva DM, Riet-Correa F, Medeiros RMT, Oliveira OF. Plantas tóxicas para ruminantes e equídeos no Seridó Ocidental e Oriental do Rio Grande do Norte. Pesquisa Veterinária Brasileira 2006; 26(4): 223-236. 10.1590/S0100-736X2006000400007

Silva JMC, Tabarelli M, Fonseca MT, Lins LV, editors. Biodiversidade da Caatinga: áreas e ações prioritárias para a conservação. Brasília: MMA, UFPE; 2003.

Silva SO, Ferreira RLC, Silva JAA, Lira MA, Alves Junior FT, Cano MOO et al. Regeneração natural em um remanescente de Caatinga com diferentes históricos de uso no agreste pernambucano. Revista Árvore 2012; 36(3): 441-450. 10.1590/ S0100-67622012000300006

Spiegel MP. Estadística, teoría y problemas resueltos. México: McGraw-Hill; 1970.

StatSoft. STATISTICA (data analysis software system), version 8.0 [Internet]. [2017?] [cited 2017 Nov. 15]. Available from: www.statsoft.com

Sunderland T, Apgaua DMG, Baldauf C, Blackie R, Colfer CJP, Cunningham $\mathrm{AB}$ et al. Global dry forests: a prologue. International Forestry Review 2015; 17(S2): 1-9. 10.1505/146554815815834813

Valentin JL. Ecologia numérica: uma introdução à análise multivariada de dados ecológicos. Rio de Janeiro: Interciência; 2000.

Velloso AL, Sampaio EVSB, Pareyn FGC, editors. Ecorregiões propostas para o Bioma Caatinga. Recife: Associação Plantas do Nordeste, Instituto de Conservação Ambiental The Nature Conservancy do Brasil; 2002.

Vieira DLM, Scariot A. Principles of natural regeneration of tropical dry forests for restoration. Restoration Ecology 2006; 14(1): 11-20. 10.1111/j.1526-100X.2006.00100.x

Vieira DLM, Scariot A, Sampaio AB, Holl KD. Tropical dry-forest regeneration from root suckers in Central Brazil. Journal of Tropical Ecology 2006; 22(3): 353-357. 10.1017/S0266467405003135

Zappi DC, Filardi FLR, Leitman P, Souza VC, Walter BMT, Pirani JR et al. Growing knowledge: an overview of Seed Plant diversity in Brazil. Rodriguésia 2015; 66(4): 1085-1113. 10.1590/2175-7860201566411

Zar JH. Biostatistical analysis. 3rd ed. New Jersey: Prentice Hall; 1996. 